\title{
HISTOPATHOLOGICAL AND IMMUNOHISTOCHEMICAL STUDY OF THE BRAIN AND HEART IN THE CHRONIC CARDIAC FORM OF CHAGAS' DISEASE
}

\author{
JOSE EYMARD HOMEM PITTELLA *, CICERO MENEGUETTE *, \\ ALFREDO J. AFONSO BARBOSA *
}

\begin{abstract}
SUMMARY - A histopathological and immunohistochemical study of the brain and heart was made in 50 patients with the chronic cardiac form of Chagas' disease. The immunohistochemical technique used was the peroxidase-antiperoxidase method adapted for the demonstration of the T. cruzi amastigotes. Histological and immunohistochemical examination of the brain showed encephalitis in multiple foci, although sparse, in four patients (8\%). In one of the patients the process was recent, active, and containing parasites. In the other three patients, the lesions were of minor intensity, with light exudative inflammatory changes, suggesting a process becoming inactive, or already inactive. The search for parasites in these three patients was negative, even with use of immunoperoxidase. The heart histological and inmunohistochemical study showed, besides the chronic myocarditis in multiple foci associated with interstitial fibrosis, amastigotes in seven patients (14\%). The absence of parasites and of inflammatory changes in the brain in the great majority of patients with chronic Chagas' disease, contrasting with the constant finding of inflammatory changes and the occasional finding of amastigotes in the myocardium of the same patients, allows us to state, in the same way other authors did, that there is no histopathological basis to support the existence of the chronic nervous form of Chagas' disease.
\end{abstract}

KEY WORDS: Chagas' disease, brain, Chagasic encephalitis, immunoperoxidase.

Estudo histopatológico e imuno-histoquímico do encéfalo e coracão na forma crônica cardíaca da doenca de Chagas.

RESUMO - Fez-se o estudo histopatológico e imuno-histoquímico sistematizado do encéfalo e coraçâo de 50 pacientes com forma crônica cardíaca de doença de Chagas. A técnica imuno-histoquímica empregada foi o método da peroxidase-antiperoxidase adaptado para a demonstração de formas amastigotas do $T$. cruzi. $O$ exame histológico e imuno-histoquimico do encéfalo revelou, em 4 casos (8\%), encefalite em focos múltiplos, não sistematizados. Num dos casos o processo era recente, em atividade, contendo parasitas. Nos outros três casos as lesões eram de menor intensidade, com fenômenos exsudativos discretos, sugerindo tratar-se de processo em extinção ou já inatipo. A pesquisa de parasitas nestes três casos, mesmo com o uso da imunoperoxidase, foi negativa. O estudo histológico e imuno-histoquimico do coração mostrou, além da miocardite crônica em focos múltiplos acompanhada de fibrose endomisial, amastigotas em 7 casos (14\%). A ausência de parasitas e de processo inflamatório no encéfalo da grande maioria dos chaǵásicos crônicos, contrastando com o achado constante de lesões inflamatórias e o encontro ocasional de amastigotas no miocárdio destes mesmos pacientes, permite afirmar, de modo semeihante a outros autores, que näo há base histopatológica para que se possa admitir a existência da forma crônica nervosa da doença de Chagas.

PALAVRas-CHAVE: doença de Chagas, encéfalo, encefalite chagásica, imunoperoxidase.

* M.D., Laboratory of Neuropathology, Department of Pathology, Federal University of Minas Gerais (UFMG) Medical School, Belo Horizonte. Aceite: 26-junho-1992.

Dr. José Eymard Homem Pittelia - Departamento de Anatomia Patológica e Medicina Legal, Faculdade de Medicina, UFMG - Av. Alfredo Balena 190 - 30130-100 Belo Horizonte MG - Brasil. 
Since Chagas' earliest papers it is known that the central nervous system (CNS) involvement by Trypanosoma cruzi (T. cruzi) may occur 8-10. In spite of its low frequency, chagasic encephalitis cases in their acute form are well known, the majority of cases affecting children under 1 year old 7,10-13,16,23,25,27, $28,31,34-36,39,43,46$. Chagas 8-10 postulated the existence of a chronic nervous form, directly caused by T. cruzi. This author has justified the existence of the chronic nervous form based on the presence of encephalitis in the acute cases 5. Still according to Chagas, the chronic nervous form would be consequent to the lesions observed in the acute form, or rather, it would represent sequelae of the encephalitis. Afterwards the author admitted that the chronic nervous form cases would be, in their majority, evolution forms of the histopathological changes 9 . However, the pathological documentation presented by him and by the authors who studied it has been poor, not allowing definitive conclusions about the existence or non-existence of an anatomical basis to characterize the chronic nervous form as postulated by Chagas $1,5,6,18,19,45$. Recent papers based on histopathological study of the brain in a great number of patients have denied the existence of an anatomical basis to characterize the chronic nervous form 33,37 . Nevertheless, recent publications about Chagas' disease, although describing minor, focal inflammatory changes in the CNS of a few patients with chronic Chagas' disease, still propose the existence of a morphological basis of the chronic nervous form 26,29 .

The development of immunohistochemical techniques which have made it possible to find with greater sensitivity and specificity the presence of many parasites (viruses, bacteria, protozoa) has led us into searching, with immunohistochemical method, amastigotes in the brain and heart of patients with chronic chagasic carditis confirmed by histopathological diagnosis. The conventional histological study of these brains was also undertaken. Thus, using similar methodology, it was possible to compare the immunohistochemical and histopathological findings in the brain and heart, the latter serving as a standard model of the Chagas' disease chronic form.

\section{MATERIALS AND METHODS}

Fifty patients with chronic cardiac Chagas' disease were studied, all of them presenting histopathological changes characteristic of chronic chagasic carditis. Among these 50 patients, 19 were retrieved consecutively in the period 1980 to 1986 in the Department of Pathology, Federal University of Minas Gerais Medical School, in Belo Horizonte. The other 31 patients had been subject of a former study33. Forty-five patients were between 20 and 60 years old $(90 \%)$, three patients were over 60 years old $(6 \%)$ and two were under 20 years old (4\%). Forty-five patients showed clinical and pathological signs of congestive heart failure. Three patients had a sudden death, without previous symptoms; other two patients died of other causes not related to the chagasic carditis. Neurologic examination was performed in all patients.

The brain, after being fixed in totum in $10 \%$ formaldehyde, was examined and sectioned by frontal sections of the cerebral hemispheres and transversal sections of the brainstem and cerebellum. Fragments were taken from the frontal, parietal, temporal and occipital lobes, basal ganglia, thalamus, hypothalamus, midbrain, pons, medulla and cerebellar hemispheres. For each patient three fragments of the heart were examined, taken from the atrium and ventricular walls. The brain and heart fragments were processed for embedding in paraffin, and 7 um-thick sections were obtained. From each brain and heart fragments two consecutive sections stained with haematoxylin and eosin and with peroxidase-antiperoxidase (PAP) were taken. The PAP tecnique used was the one introduced by Sternberger et al.42 and adapted by Barbosa 4 for the demonstration of $\mathbf{T}$. cruzi amastigotes in tisgue sections. Briefly: (1) incubate with $0.3 \%$ hydrogen peroxide during 30 minutes to block endogenous peroxidase activity; (2) incubate at $40 \mathrm{C}$ overnight with sera anti-T. cruzi (dilution 1:1000) obtained from rabbits with experimental trypanosomiasis cruzi; (3) incubate with goat anti-rabbit IgG (Miles-Yeda Ltd, Israel), dilution 1:80, at room temperature for 30 minutes; (4) incubate with rabbit PAP complex (Miles-Yeda Ltd, Israel), dilution 1:200; (5) the sections were revealed by the diaminobenzidine method under microscope control, and afterwards, counterstained with haematoxylin, dehydrated and mounted in Entelan (Merck, Brazil). Phosphate buffer solution, 0.01M, pH 7.2, was used as a diluent and as a washing solution between each step. For positive controls, heart sections of mice with acute trypa- 
nosomiasis cruzi were used; for nagative controls, the absorbed antiserum samples or normal rabbit serum samples were used, instead of rabbit anti- $T$. cruzi sera.

\section{RESULTS}

The brain sections stained with haematoxylin and eosin showed encephalitis in multiple foct, although sparse, in four patients (8\%). A detalled histopathological study of these inflammatory changes was formerly reported 33. In the four patients, the basic change was formed by inflammatory nodules composed by mononuclear cells among a variable number of microglial cells. In one of the patients (number 2), rare amastigotes forming nests close to glial cells with no inflammatory reaction, or in small accumulations surrounded by inflammatory nodules were observed (Fig. 1). The other three patients (9, 15 and 40) in which the search for amastigotes was negative showed inflammatory nodules smaller and more hypocellular than in patient 2 (Fig. 2). Except for degenerative changes in rare neurons close to or within the inflammatory nodules (patients 2) and for focel loss of neurons of the cerebelium dentate nucleus (patient 15), all the nervous tissue componunts close to the inflammatory nodules were preserved. Immunohistochemical study of the brain in patient 2 revealed the same number of amastigotes as identified in haematoxylin and eosin stained sections, however with better parasite Individualization (Fig. 3). In patients 9 , 16 and 40 , and in the 46 remaining patients, amastigotes in the sections stained with PAP were not observed. Ischemic cerebral changes, related to thromboembolic phenomena and hypoxemia following congestive heart failure and disturbances of the cardiac rhythm, were found in 74\% of the patients. A systematized pathological study of these ischemic changes was previously reported 32. Except for neurological symptomatology associated with cerebrovascular disease in some patients, no neurological manifestations that could be attributed to the inflammatory changes above mentioned were observed.

The microecopic analysis of the heart sections stained with haematoxylin and eosin showed chronic myocarditis in multiple foci, with light mononuclear intiltration in 16 patients (32\%), moderate in 28 patients (56\%) and intense in 6 patients (12\%). The inflammatory Infiltration was generally associtated with interstitial fibrosis, from discrete to mode-

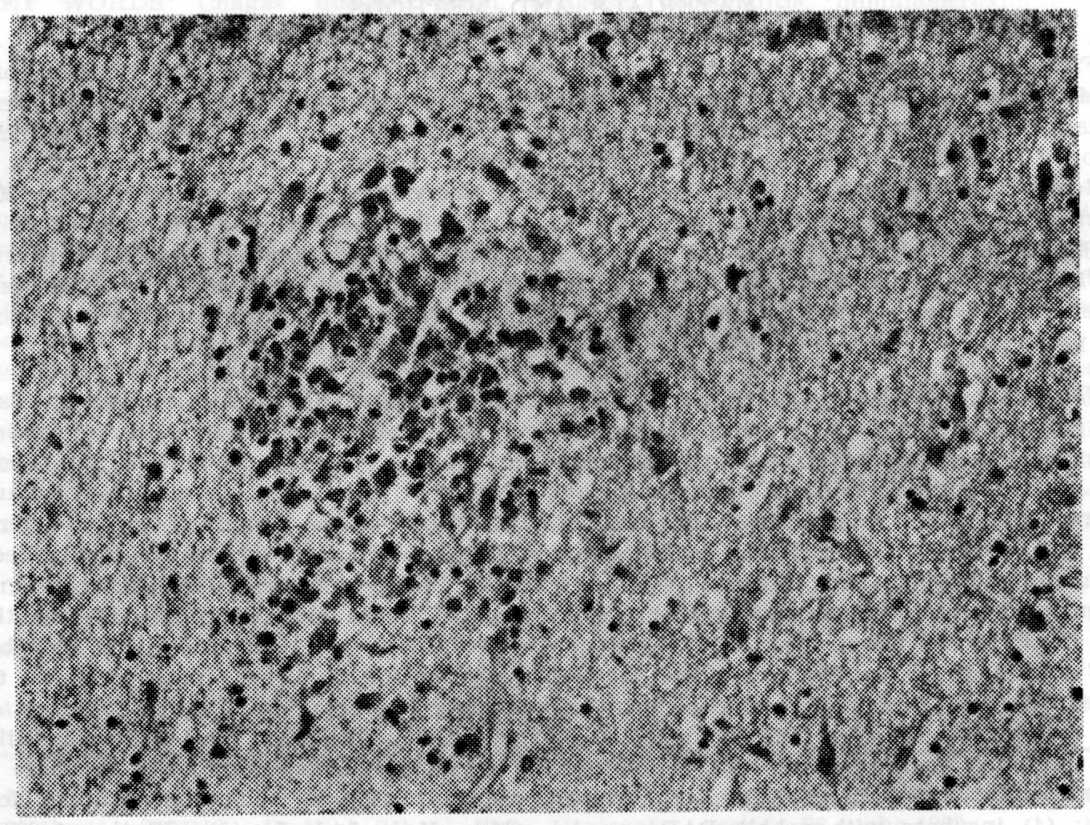

Fig. 1. Case 2. Cerebral cortex-white substance junction. Inflammatory nodule formed by mononuclear and microglial cells. Preserved neurons can be observed to the right. Haematoxylin and eosin, $X 256$. 


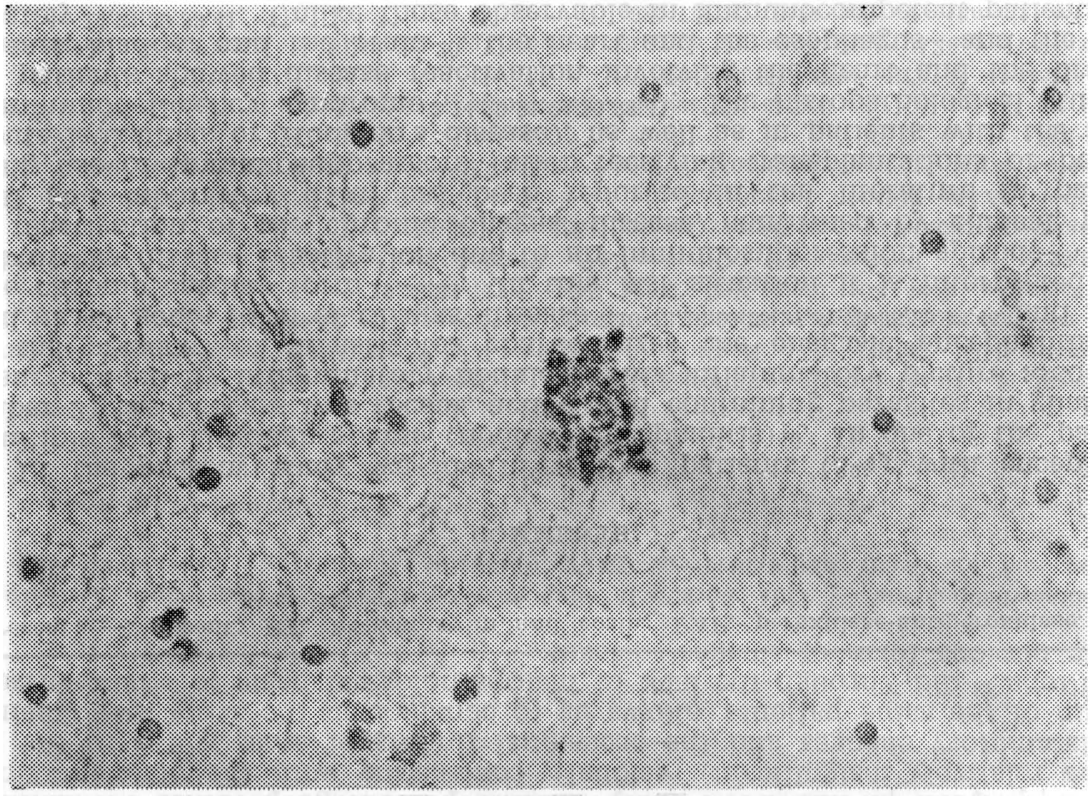

Fig. 2. Case 40. Cerebral white substance. Residual infiammatory nodule, without changes of the adjacent nervous tissue. Compare witht Fig. 1. Haematoajlin and eosin, $\mathbf{X} \mathbf{2 5 6}$.

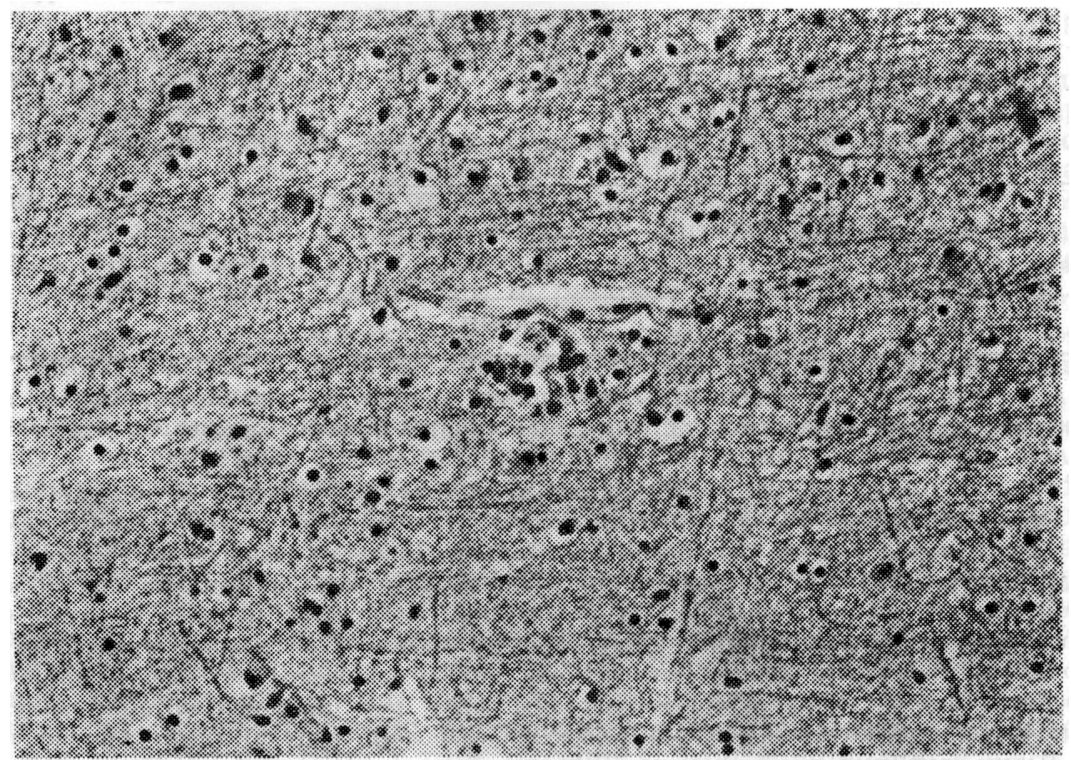

Fig. 3. Case 2. Cerebral white substance. Amastigote nest without inflammatory reaction. PAP, counterstaining with haematoxylin, $X \mathbf{2 5 6}$. 
rate. Two patients (4\%) presented amastigotes in the cardiac muscle cells and, rarely, among the inflammatory infiltrate. The other patients $(96 \%)$ did not show amastigotes in the sections stained with haematoxylin and eosin. The microscopic study of sections stained with PAP showed, besides the parasitism in the two patients already mentioned, amastigotes in other five patients, adding up to seven patients $(14 \%)$. It is interesting to point out that the only patient in which amastigotes were found in the brain (patient 2), the search of parasites in the myocardium was negative, even in the sections stained with PAP. No clinical or pathological evidence of immunosuppression was found in this patient. Data on patients presenting $T$. cruzi amastigotes in cardiac muscle cells or encephalitis with or without the presence of partasites are showed in Table 1.

Table 1. Data on chronic chagasic patients presenting $T$. cruzi amastigotes in cardiac muscle cells or encephalitis with or without the presence of parasites:

\begin{tabular}{|c|c|c|c|c|c|c|c|c|}
\hline \multirow[b]{3}{*}{ Case } & \multirow[b]{3}{*}{ Sex } & \multirow{3}{*}{$\begin{array}{l}\text { Age } \\
\text { (yrs) }\end{array}$} & \multicolumn{3}{|c|}{ Brain } & \multicolumn{3}{|c|}{ Heart } \\
\hline & & & \multirow[b]{2}{*}{ Encephalitis } & \multicolumn{2}{|c|}{ Amastigotes } & \multirow[b]{2}{*}{ Myocanditis } & \multicolumn{2}{|c|}{ Amastigotes } \\
\hline & & & & HE & PAP & & $\mathrm{HE}$ & PAP \\
\hline 2 & $\mathbf{M}$ & 35 & + & + & + & + & - & - \\
\hline 3 & $\mathbf{F}$ & 25 & - & - & - & + & - & + \\
\hline 9 & $\mathbf{M}$ & 24 & + & - & - & + & - & - \\
\hline 11 & $\mathbf{M}$ & 48 & - & - & - & + & - & + \\
\hline 15 & $\mathbf{M}$ & 60 & + & - & - & + & - & - \\
\hline 19 & $\mathbf{M}$ & 37 & - & - & - & + & - & + \\
\hline 30 & M & 56 & - & - & - & + & + & + \\
\hline 31 & $\mathbf{M}$ & 50 & - & 一 & - & + & - & + \\
\hline 34 & M & 20 & - & - & - & + & + & + \\
\hline 37 & $\mathbf{F}$ & 48 & - & - & - & + & - & + \\
\hline 40 & $\mathbf{F}$ & 44 & + & - & - & + & - & - \\
\hline
\end{tabular}

†, present; -, absent; HE, haematoxylin and eosin; PAP, peroxidase-antiperoxidase.

\section{COMMENTS}

In the present study we identified four patients $(8 \%)$ with encephalitis in multiple foci, although sparse (nodular encephalitis) ${ }^{40}$. In one of the patients (number 2) the process was recent, active, and containing parasites in glial cells and surrounded by inflammatory nodules. This inflammatory picture associated with the presence of amastigotes characterizes the chagasic encephalitis described in the acute form of Chagas' disease $7,10-13,16,23,25,27,31,34-36,39,43,46$ and rarely in the chronic cardiac form 19,28,33. In this last situation it is interpreted as a result of the disease reactivation due to an immunosuppression episode 28,33 . In fact, reactivation of the chronic Chagas' disease, confirmed by clinical, pathological and laboratory data, has been reported in the literature in patients making use of immunosuppressors (after receiving transplantations or because of acute leukemias or Hodgkin's disease), as well as in patients with the acquired immunodeficiency syndrome $2,14,20,21,24,30,38,41$. The histopathological study of these patients showed disease reactivation involving the heart and the brain 28 , the heart, bladder and the brain 20 , the heart and the esophagus 2 and the brain separately 14,24,30,33,41. Unlike those observable in immunocompetent patients, the cerebral lesions in immunosuppressed patients are often volumous, forming single or multiple necrotic masses. Rarely, the parasites could not be found in the examined viscera and, then, the diagnosis of Chagas' disease reactivation was based on laboratory studies 35 . 
When a non-immune host is infected with T.cruzi the parasites are widely destroyed by macrophages at the inoculation site 44 . However, the organisms which escape from the macrophages transform into trypomastigotes which can infect non-phagocytic cells, mainly cardiac muscle, skeletal muscle, and glial cells. The appearance of an efficient immune response against $T$. cruzi is responsible for reduction of the blood and tissue parasitism to virtually undetectable levels, providing the host with a solid acquired resistance 15,22. In the chronic phase, spontaneous relapses are not observed, unless after the host immunosuppression. The immune response in the chronic phase still precludes parasitaemia elevation (reappearance of the acute phase), even in the experimentally reinoculated hosts. However, the acquired immunity is not the sterilizing type, that is, it does not destroy the first infection parasites totally or the ones reinoculated afterwards 22 . Thus the host remains infected for the rest of its life; some structures as the suprarenal central vein may act as a parasite reservoir 3 and contribute to the disease reactivation when there is some immunosuppressive episode.

The other three patients analysed in this present work (patients 9, 15 and 40), who presented brain inflammatory changes, had minor lesions, with light exudative phenomena, suggesting a process becoming inactive, or already inactive, which could represent sequelae of the acute form. The search for parasites in these three patients was negative, even with PAP. The small dimensions and the low cellularity of these inflammatory nodules, as well as the absence of parasites, allows us to interpret these lesions as the final regression phase of the inflammatory nodule of the acute form 33 . Such interpretation would also be valid for the minor, focal inflammatory changes, also devoid of parasites, described by other authors in the brain of some chagasic patients with the chronic cardiac form 29,37 .

In $92 \%$ of the chronic chagasic patients examined, neither parasites, inclusively through a sensitive and specific immunohistochemical method, nor inflammatory changes in the brain were observed. This fact strongly suggests that these individuals would not have had a CNS infection in the acute phase of Chagas' disease or, alternatively, they would have presented mild encephalitis, in very sparse foci, with total regression of the lesions. The absence of parasites and inflammatory nodules in the brain in the great majority of chronic chagasic patients analysed in this work (only a small percentage presents inflammatory changes relatively insignificant, residual), contrasting with the constant finding of inflammatory changes and the occasional finding of amastigotes in the myocardium of the same patients, allows us to conclude in the same way Queiroz 37 and Pittella 33 did, through the lack of histopathological basis to characterize the chronic nervous form of Chagas' disease.

Acknowledgements - This work was supported by FINEP (Financiadora de Estudos $e$ Projetos) and by Grant 302036/76 from CNPq (Conselho Nacional de Desenvolvimento Científico e Tecnológico).

\section{REFERENCES}

1. Alencar A. Encefalopatia crônica chagásica. J Bras Neurol 1982, 18:7-12.

2. Almeida HO, Tafuri WL, Bogliolo L, Cunha JC. Parasitismo incomum do miocárdio e do eŝfago em chagásico crônico, portador de doença de Hodgkin e em uso de imunodepressores, Rev Soc Bras Med Trop 1974, 8:117-121.

3. Almeida HO, Teixeira VP, Oliveira AC. Flebite com parasitismo em supra-renais de chagásicos crônicos. Arq Bras Cardiol 1981, 36:341-344.

4. Barbosa AJA. Método imunocitoquímico para a identificação de amastigotas do Trypanosoma cruzi em cortes histologicos de rotina. Rev Ins Med Trop São Paulo 1985, 27: 293-297.

5. Borges-Fortes A. As lesões do sistema nervoso na enfermidade de Chagas (tripanosomiase americana). J Clin 1942, 23:353-361..

6. Borges-Fortes A. As lesões do sistema nervoso na enfermidade de Chagas (tripanosomiase americana). J Clin 1945, $26: 277-286$.

7. Cardoso RA. Lesões do sistema nervoro central em 4 casos infantis agudos de doença de Chagas. Bol Inst Puer Univ Brasil 1960, 17:101-110.

8. Chagas C. Nova entidade mórbida do homem: resumo geral de estudos etiológicos e clínicos. Mem Inst Oswaldo Cruz 1911, 3:219-275. 
9. Chagas C. Les formes nerveuses d'une nouvelle trypanosomiase: Trypasosoma cruzi inocule par Triatoma magista (maladie de Chagas). Nouv Iconogr Salpêtrière 1913, 26:1-9.

10. Chagas C. Triapanosomiase americana: forma aguda da molestia. Mem Inst Oswaldo Cruz 1916, $8: 37-59$.

11. Decourgey E. The first fatal case of Chagas' disease observed on the isthmus of Panama. Am J Trop Med 1935, 15:33-40.

12. Dominguez A, Gavallér B. Encephalitis chagasica. Z Tropenmed Parasitol 1962, 13:308-311.

13. Elejalde $P$. Lesões cerebrais na doença de Chagas aguda. An Paul Med Cir 1958, 76:348-350.

14. Ferrelra MS, Ferreira RG, Oliver W, Rocha A, Silva AM. Meningoencefalite aguda causada pelo Trypanosoma cruzi em paciente portador da síndrome da imunodeficiência adquirida (AIDS). Rev Soc Bras Med Trop 1989, 22(Suppl2):91.

15. Hudson L, Britten V. Immune response to south american trypanosomiasis and its relationship to Chagas'disease. Br Med Bull 1985, 41:175-180.

16. Johnson CM, DeRivas GT. Six new cases of Chagas' disease in Panama with review of previous cases. Am J Trop Med Hyg 1936, 16:47-57.

17. Jörg Mv. Histopatologia neural en disfunción cerebral mínima, secuela de meningoencefalitis por Trypanosoma cruzi. Prensa Med Argent 1978, 65:229-238.

18. Jörg ME, Rovira IZ. Formas clínicas encefalopáticas de enfermedad de Chagas crónica observadas en la Argentina. Prensa Med Argent 1980, 67:757-764.

19. Jörg ME, Orlando AS. Neurosindrome minimo en la tripanosomiasis cruzi crónica (estudio de dos casos de encefalopatia chagásica crónica). Mem Inst Oswaldo Cruz 1967, 65:63-79.

20. Jost L, Turin M, Etchegoyen F, Leiguarda R, Torcuato A, Iotti R. Meningoencefalitis chagésica en paciente con tratamiento inmunosupresor por trasplante renal. Rev Neurol Arg 1977, 3:425-428.

21. Kohl S, Pickering LK, Frankel LS, Yaeger RG. Reactivation of Chagas' disease during therapy of acute lymphocytic leukemia. Cancer 1982, 50:827-828.

22. Krettli AU. Resposta imune humoral na doença de Chagas. Interciência 1983, 8:374-383.

23. Laranja FS, Dias E, Nóbrega G, Miranda A. Chagas' disease: A clinical, epidemiologic, and pathologic study. Circulation 1956, 14:1035-1060.

24. Leiguarda R, Roncoroni A, Taratuto AL, Jost L, Berthier M, Nogues M, Freilig H. Acute CNS infection by Trypanosoma cruzi (Chagas' disease) in immunosuppressed patients. Neurology 1990, 40:850-851.

25. Lisbôa AC. Sobre a forma congênita da doença de Chagas: estudo anátomo-patológico de 6 casos. Rev Inst Med Trop São Paulo 1960, 2:319-334.

26. Lopes ER, Chapadeiro E, Tafuri WL, Prata AR. Doença de Chagas. In Chapadeiro E, Lopes ER, Raso P, Tafuri WL (eds): Bogliolo Patologia. Ed 4 Rio de Janeiro: Guanabara Koogan, 1987, p 1047-1065.

27. Lundeberg KR. A fatal case of Chagas" disease occurring in a man 77 years of age. Am J Trop Med Hyg 1938, 18:185-196.

28. Mattosinho-França LC, Fleury RN, Ramos HA Jr, Lemos S de, Melaragno Filho R, Pasternak J. Moléstia de Chagas crônica associada a leucemia linfática: ocorrência de encefalite aguda como alteração do estado imunitário. Arq Neuro-Psiquiat (São Paulo) 1969, 27:59-66.

29. Menezes AC, Lopes ER, Chapadeiro E. Estudo anatomopatológico sistematizado de encéfalos de chagásicos crônicos falecidos subitamente. Rev Inst Med Trop são Paulo 1988, 30:441-442.

30. Monteverde DA, Taratuto AL, Lucatelli N. Meningoencefalitis chagásica aguda en pacientes inmunosuprimidos. Rev Neurol Arg 1976, 2:260-266.

31. Noetzel $\mathbf{H}$ von, Elejalde $P$, Dias $\mathrm{E}$. Über die Gehirmveränderungen bei der Chagaskrankheit. Z Tropenmed Parasitol 1958, 9:27-32.

32. Pittella JEH. Ischemic cerebral changes in the chronic chagasic cardiopathy. Arq Neuro-Psiquiat (São Pauio) 1984, 42:105-115.

33. Pittella JEH. Brain involvement in the chronic cardiac form of Chagas' disease. J Trop Fied Hyg 1985, 88:313-317.

34. Queiroz AC. Tumor-like lesion of the brain caused by Trypanosoma cruzi. Am J Trop Med Hyg 1973, 22:473-476.

35. Queiroz AC. O envolvimento do sistema nervoso central em algumas doenças parasitárias. J Bras Med 1976, 30:26-38.

36. Queiroz AC. Estudo das alterações encefálicas em casos humanos agudos da doença de Chagas. Rev Pat Trop 1978, 7:13-22.

37. Queiroz AC. Estudo anatomopiatológico do encéfalo na forma crônica da doença de Chagas. Rev Pat Trop 1978, 7:135-145.

38. Rivero I, Boris E, Moravenik M, Morales JA, Gomez ME, Rosas JM. Leucemia aguda $y$ enfermedad de Chagas: estudio de 4 casos. Medicina 1975, 35:73-78. 
39. Rubio M, Howard J. Congenital Chagas' disease: II. Pathological tindings in nine cases. Bol Chil Parasitol 1968, 23:113-121.

40. Scaravilli F. Parasitic and fungal infections of the nervous system. In Hume Adams J, Corsellis JA, Duchen LW (eds): Greenfield's Neuropathology. Ed 4. London: Edward Arnold, 1984, p 304-337.

41. Sevlever G, Taratuto AH, Carreras MC de las, Leiguarda $R$, Nogues M. Catatonia secondary to acute Chagas' encephalitis. J Neurol Neurosurg Psychiatry 1987, 50:1244.

42. Sternberger LA, Hardy PH, Cuculis JJ, Meyer HG. The unlabeled antibody-enzyme method of immunocytochemistry: preparation and properties of soluble antigen-antibody complex (horseradish peroxidase-antihorsenadish peroxidase) and its use in identification of spirochetes. $\mathrm{J}$ Histochem Cytochem 1970, 18:315-333.

43. Teixeira AR, Roters FA, Mott KE. Acute Chagas' disease. Gaz Méd Bahia. 1970, 3:176-186.

44. Teixeira ARL. Chagas' disease: trends in immunological research and prospects for immunoprophylaxis. Bull WHO 1979, 57:697-710.

45. Torres CM. A tripanosomose americana e a sua anatomia patológica. Fol Méd 1923, 4:25-29.

46. Vianna G. Contribuição para o estudo da anatomia patológica da «Moléstia de Carlos Chagas». Mem Inst Oswaldo Cruz 1911, 3:276-294. 